Wojciech Kluj ${ }^{1}$

Uniwersytet Kardynała Stefana Wyszyńskiego, Warszawa, Polska

Wydział Teologiczny

\title{
Chrześcijańsko-muzułmańskie relacje w Azji Centralnej do czasów Timura (XIV wiek)
}

Studia nad Azją Centralną są w Polsce znane. Na szczególną uwagę zasługują liczne prace Tadeusza Bodio i badania archeologiczne Barbary Kaim². W epoce wzmożonych relacji międzyreligijnych i wielkich zmian społecznych we współczesnym świecie słuszne wydaje się zwrócenie baczniejszej uwagi na jedną z największych duchowych „bitew” między misjonarzami chrześcijańskimi i muzułmańskimi, która miała miejsce w XIII-XIV wieku na stepach Azji Centralnej, ponieważ jej konsekwencje trwają do dziś.

Słynny historyk misji Kenneth Scott Latourette napisał kiedyś:

Gdyby Rzym w trzecim i czwartym wieku podbił Persję i utrzymał te tereny wystarczająco długo, aby umożliwić chrześcijaństwu stać się panującą religią, być może arabska inwazja zostałaby zatrzymana przy granicy, a islam ograniczył się do Arabii i wtedy chrześcijaństwo zdobyłoby miejsce w Azji Centralnej, które teraz posiada islam. Lub też gdyby chrześcijaństwo zdobyło Persję, podobnie jak

\footnotetext{
${ }^{1}$ Wojciech Kluj OMI - dr hab., prof. UKSW, wykładowca na Uniwersytecie Kardynała Stefana Wyszyńskiego w Warszawie, zastępca dyrektora Instytutu Nauk Teologicznych UKSW. Specjalizuje się w badaniach dotyczących tłumaczenia wiary na inne języki i kultury oraz problematyki Kościoła w Azji. Przewodniczący Międzynarodowego Stowarzyszenia Misjologów Katolickich (International Association of Catholic Missiologists), członek Stowarzyszenia Misjologów Polskich oraz International Association for Mission Studies; e-mail: w.kluj@uksw.edu.pl. ORCID: 0000-0002-3888-7669.

${ }^{2}$ Piszą o tym współcześnie również inni uczeni w polskich periodykach, na przykład: C. Francavilla, The site of Shaym Qal'a, Marw oasis: reconsidering the chain of information, „Historia i Świat” 8 (2019), s. 79-90. Powstają też prace bardziej szczegółowe, takie jak chociażby: S. Żerańska-Kominek, A. Lebeuf, Opowieść o szalonej Harman i Aszyku zakochanym w księżycu. Postać muzyka i koncepcja muzyki w turkmeńskim dessanie „,Harman Däli”, Kraków 1998.
}

PST 39, 2021: 161-183. (C) The Author(s), Adam Mickiewicz University Press, 2021. Open Access article, distributed under the terms of the CC licence (BY-NC-ND, https://creativecommons.org/licenses/by-nc-nd/4.0/). 
Armenię, zanim zostało utożsamione z Cesarstwem Rzymskim, przyszłość mogła być znacznie inna ${ }^{3}$.

To stwierdzenie odnosi się do sytuacji w pierwszym tysiącleciu, ale niemniej ważne procesy miały miejsce w XII-XIV wieku w Azji Centralnej. W teologii „podbój” terytorialny nie jest najwyższym celem, a w historii nie ma miejsca na spekulowanie, lecz warto przeanalizować tę sytuację, bo może ona mieć odniesienia do współczesności.

W epoce dialogu ekumenicznego przyzwyczailiśmy się już do spoglądania na wspólnie dziedzictwo chrześcijańskie Kościołów prawosławnych czy wspólnot powstałych w duchu reformacji. Stale brakuje jednak podobnego spojrzenia na wspólnoty chrześcijańskie Kościołów Wschodu ${ }^{4}$. Mimo iż nie używa się już pejoratywnych epitetów ani w odniesieniu do tradycji chrześcijańskich Kaukazu (ormiańskie i gruzińskie), Indii (malabarskich i malankarskich), ani w odniesieniu do Afryki północnowschodniej (koptyjska, etiopska), to jednak stale stosuje się takie (niepoprawne) określenia jak „nestoriańskie” czy „monofizyckie” w odniesieniu do przedchalcedońskich Kościołów Wschodus. Owe Kościoły, wywodzące się z tradycji syryjskich (antiocheńskich), bywają niekiedy nazywane ,prawosławnymi”. W celu uniknięcia nieporozumień proponuję pozostawić określenie - „prawosławne” - Kościołom tradycji greckiej (konstantynopolitańskiej), a Kościoły przedchalcedońskie nazywać „orientalnymi”.

Pozostawiwszy szczegóły dyskusji doktrynalnych specjalistom w dziedzinie teologii systematycznej i ekumenizmu ${ }^{6}$, odwołamy się tutaj do Wspólnej

${ }^{3}$ K.S. Latourette, A History of the Expansion of Christianity, t. II: The Thousand years of Uncertainty, A.D.500-A.D.1500, Grand Rapids 1973, s. 264-265 (thum. W. Kluj).

${ }^{4}$ Świadomość istnienia „trzeciego płuca” Kościoła nie „przebiła się” jeszcze do powszechnego rozumienia wiary. Por. M. Sadowski, ,, Trzecie płuco” chrześcijaństwa? Jan Pawet II a Kościoły tradycji syryjskiej, „Studia Włocławskie” 16 (2014), s. 245-261.

${ }^{5}$ Aby obalić błędy nestorianizmu potępionego na Soborze Efeskim w 431 roku, powstał monofizytyzm. Głosił, że Jezus Chrystus ma jedną, złączoną naturę bosko-ludzką (boska „wchłonęła" ludzką). Nauczanie to uznano za herezję na Soborze Chalcedońskim w 451 roku. Tej decyzji nie poparła część wiernych z terenów wykazujących tendencje separatystyczne wobec kultury greckiej, czyli między innymi z Syrii i Egiptu. Prześladowanie monofizytów spowodowało ich przemieszczenie się na wschód, poza tereny wpływów Cesarstwa Bizantyńskiego. Współczesny dialog ekumeniczny wskazuje, że sporo nieporozumień wynikało nie tyle z treści wiary, ile raczej z różnorodności kultur i rozmaitego zakresu pojęć teologicznych w różnych językach.

${ }^{6}$ Autor Dziejów Apostolskich pisał do Greków. Odkrycia z Qumran i z Nag Hammadi ukazują rozwój chrześcijańskiej tradycji niegreckiej. Analogicznie, tak jak św. Paweł był wielkim apostołem na zachodzie, tak św. Tomasz był wielkim apostołem na wschodzie. Pod koniec II wieku istniało już ponad 20 biskupstw w Persji, a chrześcijanie byli obecni na terenach dzisiejszej Arabii i Afganistanu. Por. J. Daniélou, Teologia judeochrześcijańska. Historia doktryn chrześcijańskich przed Soborem Nicejskim, thum. S. Basista, Kraków 2002; T.V. Philip, The Missionary Impulse in the Early Asian Christian Traditions, „International Review of Mission” 85 (1996), s. 508-509. 
Deklaracji Chrystologicznej, podpisanej w dniu 11 listopada 1994 roku przez Jana Pawła II (reprezentującego Kościół rzymskokatolicki) i Mara Dinkę IV (ze strony Asyryjskiego Kościoła Wschodu, zwanego niesłusznie „,nestoriańskim”). Czytamy w niej między innymi:

różne wyrażenia tej samej wiary są uprawnione i dokładnie szanujemy pierwszeństwo, które każdy Kościół im daje w swoim życiu liturgicznym i w swej pobożności. (...) Kontrowersje przeszłości doprowadziły do anatem dotyczących osób i sformułowań. (...) dziś lepiej rozumiemy, iż wytworzone podziały spowodowane były w znacznej mierze nieporozumieniami (...) żyjąc tą wiarą i tymi sakramentami lokalne Kościoły katolickie i lokalne Kościoły asyryjskie mogą wzajemnie uznać się jako Kościoły siostrzane?

Choć pełnej jedności w wierze jeszcze nie osiągnęliśmy, to jednak łączność sakramentalna została uznana za dość mocną, skoro w deklaracji proponuje się nawet współpracę w formowaniu przyszłych kapłanów. Po upływie trzech miesięcy od tej deklaracji (2 V 1995), w liście apostolskim Orientale Lumen Jan Paweł II, mając zapewne w pamięci to wydarzenie, napisał: „tradycja Kościołów Wschodnich stanowi integralną część dziedzictwa Kościoła Chrystusowego" (nr 1).

W interesującym nas okresie chrześcijanie Orientu stale określali siebie jako Nasraye (Nazarejczycy), a więc formułą zachowującą aramejski termin używany przez apostołów. Kościoły Wchodu znały Jezusa jako Jeszuę, używały tekstów, o których większość chrześcijan w Europie Zachodniej zapomniała. Nie znając współczesnych odkryć w Qumran, chrześcijanie azjatyccy stale mieli dostęp do wielu alternatywnych, starożytnych tekstów Pisma Świętego.

Ponieważ religie Azji Centralnej okresu IV-XIII wieku nie są polskiemu czytelnikowi dobrze znane, konieczne jest poszerzenie artykułu o kontekst historyczny. Takie tereny jak współczesny Afganistan czy Tybet posiadały aktywne misyjnie, otwarte centra chrześcijańskie na długo przez narodzeniem Mahometa. Aby tekst nie obejmował zbyt wielu szczegółów, przyjrzymy się interesującemu nas procesowi z perspektywy głównego miasta tego regionu, jakim był starożytny Merw.

\section{Kontekst historyczny Azji Centralnej}

Termin „Azja Centralna” (lub „Azja Środkowa”) nie jest precyzyjny. W węższym znaczeniu odnosi się do pięciu poradzieckich „stanów”, czyli: Kazach-

${ }^{7}$ Tekst oficjalny, https://www.vatican.va/content/john-paul-ii/en/speeches/1994/november/do cuments/hf_jp-ii_spe_19941111_dichiarazione-cristologica.html [dostęp 04.08.2021]. Tlumaczenie na język polski: Wspólna dek̄laracja chrystologiczna Kościoła katolickiego i Asyryjskiego Kościola Wschodu, „Studia Theologica Varsaviensia” (1997) nr 2, s. 349-351. 
stanu, Kirgistanu, Uzbekistanu, Turkmenistanu i Tadżykistanu, a w szerszym również do terenów chińskiego Turkiestanu na wschodzie oraz północnych terenów dzisiejszego Iranu, Afganistanu, Pakistanu, a nawet po trosze Indii.

Geograficznie Azję Centralną (w interesującym nas okresie zwaną Transoksanią̧ $\left.{ }^{8}\right)$ można podzielić na trzy strefy. Pierwszą jest pas oaz, ciągnący się od Iranu do Chin wzdłuż głównych dolin rzecznych, przeważnie przez Turkmenistan i Uzbekistan. Drugą stanowi pas stepów i pustyń na północy i w centrum (Kazachstan) oraz na dalekim południu (Turkmenistan). Trzecią jest wysoka strefa górska na południowym wschodzie (Badachszan w Tadżykistanie i północnym Afganistanie).

Azja Centralna nie stworzyła trwałej jedności politycznej. Wiele grup etnicznych walczyło ze sobą. Zmieniały się ościenne państwa i panujące, potężne dynastie. Utwierdzały one swoje wpływy polityczne i ekonomiczne siłą militarną. Również koczownicze plemiona z północnych stepów często najeżdżały te ziemie, nierzadko powodując znaczne zniszczenia. Nawet tak potężne imperia jak państwa Kuszanów, Sasanidów czy Chiny dynastii Tang albo Tybet nigdy zdołały doprowadzić do zjednoczenia całej Azji Środkowej pod ich panowaniem, a granice etniczne nie były identyczne z granicami językowymi, religijnymi czy politycznymi.

Ludność zamieszkująca pas oaz Azji Środkowej miała przeważnie irańskie korzenie, lecz obecny był też znaczny element turecki ${ }^{9}$. Dość mocno rozwijała się kultura miejska, szczególnie w takich miastach jak: Merw, Samarkanda czy Buchara. Ponadto Jedwabny Szlak, czyli transkontynentalna sieć połączeń handlowych, łączył tereny Azji Centralnej z Chinami, Indiami i Iranem, a także z Morzem Czarnym i Europą. Głównymi religiami tego pasa oaz były wpierw (przed Chrystusem) buddyzm i zoroastryzm, a później manicheizm i islam. Zauważalna była również obecność żydowska, zwłaszcza w miastach. Stopniowo już od II-III wieku w głównych miastach Azji Centralnej zakładano także wspólnoty chrześcijańskie. Najstarsze, potwierdzone biskupstwo w tym regionie, mianowicie w Merw, istniało już w IV stuleciu, a w Samarkandzie w VI wieku ${ }^{10}$.

${ }^{8}$ Z łac. trans i Oxus, czyli „za Oksusem”, to jest za Amu-Darią. Chodzi o międzyrzecze: pomiędzy Amu-Darią i Syr-Darią. Właśnie w tym regionie, w XIV wieku przyszedł na świat Timur (Tamerlan), główna postać interesującego nas procesu.

${ }^{9}$ W celu uproszczenia zastosuję nazwę: Turcy. Starożytne ludy tureckie bywają też określane jako turkijskie, turańskie, turskie czy turkskie. Od mniej więcej VI wieku po Chr. emigrowały z regionów Ałtaju (obecnie pogranicze Rosji, Kazachstanu, Chin i Mongolii). W swojej intensywnej ekspansji zasiedlały kolejne tereny aż po Europę. W średniowieczu tworzyły liczne państwa. Jedno z nich, imperium Turków osmańskich, przetrwało ponad 700 lat. Inne rozpadały się szybciej. Obecnie istnieje sześć narodowych państw tureckich: Azerbejdżan, Kazachstan, Kirgistan, Turkmenistan, Turcja i Uzbekistan oraz wiele innych mniejszych regionów.

${ }^{10}$ Por. W. Kluj, Zmienne dzieje Kościoła w Azji Środkowej, w: „Ecclesia in Asia”. Wybrane problemy Kościoła w Azji w świetle posynodalnej adhortacji Jana Pawła II, red. J. Różański, 
Pas stepów i pustyń zamieszkiwali pasterze-nomadzi, w zasadzie tureckojęzyczni. Koczowniczy rytm życia uniemożliwiał ustanowienie instytucji centralnych. Było to z jednej strony utrudnieniem dla każdej z religii, która chciałaby zakorzenić się w tym regionie, a $\mathrm{z}$ drugiej strony pozyskanie nomadów dawało danej religii silną pozycję.

Strefę wysokogórską i dolinę Badachszanu zamieszkiwały od niepamiętnych czasów małe plemiona pamirskie o pochodzeniu wschodnioirańskim. Ludność Pamiru była prawie całkowicie odizolowana od innych społeczności, zarówno osiadłych, jak i nomadów. Tutaj również dostęp jakiejkolwiek nowej religii był utrudniony ${ }^{11}$.

Aleksander Macedoński (356-323 przed Chr.) pozostawił w Baktrii i Sogdianie greckich osadników stanowiących oparcie dla władzy Seleucydów i państwa Greków Baktryjskich. Około 140 roku przed Chr. Baktrię opanowali Sakowie popierający buddyzm. W III wieku po Chr. ich państwo podbili Sasanidzi. Pod koniec IV wieku pojawili się tam Heftalici zwani też „Białymi Hunami”. Pokonali oni Sasanidów ${ }^{12}$. Później dominującą siłą w Azji Centralnej stali się Turcy, którzy sprawowali kontrolę nad - ciągle irańskimi - Baktrią i Sogdianą. Ta ostatnia przeżywała, od VI do VIII stulecia, swój „złoty wiek”. Jej kupcy „zawładnęli” Jedwabnym Szlakiem, a język sogdyjski stał się językiem komunikacyjnym Szlaku ${ }^{13}$. Rozmaite, mniejsze ludy tureckie tworzyły na tym terenie swoje państwa, począwszy od VI aż po XI wiek. Na terenach Azji Centralnej, między Mongolią a Morzem Kaspijskim, przez pewien okres istniały państwa: Karłuków, Ujgurów, Połowców, Chazarów, Kirgizów czy Oguzów.

Chrześcijanie żyli we wszystkich tych państwach. Nie były one jednak zbyt stabilne i nie trwały długo. Aby wiara mogła się dobrze zakorzenić w danej kulturze, trzeba było dłuższego okresu. Niektóre z tych państw miały nawet dość liczną procentowo wspólnotę chrześcijan. Pierwszą większą i trwalszą strukturę państwową w Azji Centralnej wprowadzili dopiero Arabowie. Armia arabska zajęła Chorasan (obecnie: Turkmenistan i Uzbekistan) i Transoksanię w połowie

Warszawa 2004, s. 143-159; tenże, Chrześcijaństwo w starożytności i średniowieczu na terytoriach wspótczesnego Turkmenistanu, w: Turkmenistan. Historia - społeczeństwo - polityka, red. T. Bodio, Warszawa 2005, s. 479-485. O obecności dokumentów rozmaitych religii (również chrześcijańskich) w chińskiej części Jedwabnego Szlaku na podstawie odkryć ostatniego stulecia: P. Hopkirk, Obce diabły na Jedwabnym Szlaku. W poszukiwaniu zaginionych miast i skarbów w chińskiej części Azji Środkowej, tłum. A. Bezpiańska-Oglęcka, Warszawa 2008.

${ }^{11}$ Por. L. Gumiłow, Śladami cywilizacji Wielkiego Stepu, tłum. S. Michalski, Warszawa 2004. Ta pozycja jest interesującą analizą historii z perspektywy średniowiecznej legendy o państwie chrześcijańskiego króla-kapłana Jana właśnie w Azji Centralnej.

${ }^{12}$ Pomogli odzyskać tron Kawadowi I (488-531), co później okazało się ważne z perspektywy obecności chrześcijańskiej.

${ }^{13}$ Do chrześcijańskiej tradycji liturgicznej języka sogdyjskiego odwoływali się w słynnej dyspucie weneckiej święci Cyryl i Metody. 
VII wieku. W 705 roku Qutayba ibn Muslim, który został gubernatorem Chorasanu, założył swoją stolicę w Merw. Abbasydzi przejęli władzę nad imperium islamskim w 750 roku po pokonaniu wcześniejszej dynastii Umajjadów. Przez dwa wieki przeżywała ona rozkwit. W 762 roku stolica kalifatu została przeniesiona z Damaszku do Bagdadu. Umajjadowie chętnie przyjmowali na swym dworze niearabskich muzułmanów. $Z$ jednej strony pomagało to $w$ integrowaniu w państwie kultur arabskich i perskich, jednak z drugiej strony raziło ich arabskich zwolenników z Chorasanu. Ponadto Abbasydzi byli stale w wewnątrzislamskim konflikcie z szyitami.

Ponieważ pozycja Abbasydów w państwie muzułmańskim nie była pewna, zdecydowali się na powołanie do istnienia własnej armii składającej się głównie z najemników pochodzenia tureckiego i irańskiego, popularnie zwanych Turkami. W połowie IX wieku armia ta przejęła faktyczną kontrolę kalifatu. W 1055 roku Turcy Seldżuccy ${ }^{14}$ zdobyli Bagdad. Z czasem Seldżuków (pod koniec XII) z Iraku wypchną chorezmszachowie. Ostatecznie, zarówno Chorezm, jak i Bagdad podbiją Mongołowie. W tym artykule interesuje nas przede wszystkim, jak doszło do tego, że ostatecznie władcy mongolscy ulegli islamizacji i nie przyjęli wiary chrześcijańskiej ${ }^{15}$.

\section{„Wielki” Merw - Marw Al-Shāhijān}

W interesującym nas okresie Merw było największym miastem owego regionu, zatem przyjrzymy się bliżej sytuacji panującej w tym mieście. Stanowiło ono najważniejsze miasto Azji Centralnej na historycznym Jedwabnym Szlaku (pozostałości Merw znajdują się w pobliżu dzisiejszego Mary w Turkmenistanie). Na przestrzeni wieków wielokrotnie przechodziło w różne ręce. Panowali w nim starożytni Macedończycy, Partowie, Arabowie, Ghaznawidzi, Seldżukowie, Chorezmijczyczy, Timurydzi, Persowie, Uzbecy i Rosjanie.

Merw było miastem ważnym dla wszystkich religii Azji Centralnej. Dzięki archeologicznym odkryciom wiemy, że było ono miastem kosmopolitycznym,

${ }^{14}$ Określenie „Turcy Seldżuccy” oznacza Turków pod władzą rodu wywodzącego się od Seldżuka. Dopiero w X wieku Seldżucy przeszli na islam. Naciskani przez Oguzów i Karachanidów, początkowo oferowali swoje usługi wojenne rozmaitym władcom Azji Centralnej. W 1040 roku udało się im utworzyć własne państwo. W 1055 roku zajęli Bagdad, a wnuk Seldżuka otrzymał tytuł: sułtan. Państwo Wielkich Seldżuków stanowiło luźny zbiór krajów rządzonych przez poszczególnych władców, w rozmaitym stopniu uznających podległość władzy centralnej. Ostatnim, Wielkim Seldżukiem był Ahmad Sandżar, który zginął w Merw w 1157 roku.

${ }^{15}$ Szerzej: por. B. Gafurow, Dzieje i kultura ludów Azji Centralnej. Prehistoria. Starożytność. Średniowiecze, thum. S. Michalski, Warszawa 1978. 
w którym istniały wspólnoty: zoroastryjczyków ${ }^{16}$, buddystów, manichejczyków, żydów, chrześcijan i oczywiście muzułmanów rozmaitej proweniencji.

Panowanie Sasanidów w Merw zakończyło się wtedy, gdy ostatni władca owej dynastii - Jezdegerd III (632-651) ${ }^{17}$ - został zabity w okolicy, a jego armia poddała się Arabom. Pochował go chrześcijański biskup. Miasto stało się stolicą prowincji Chorasan za rządów muzułmańskiej dynastii Umajjadów. W 671 roku przysłano do Merw 50 tysięcy Arabów, żeby je skolonizować. Traktując miasto jako bazę wypadową, w latach 705-715 Arabowie podporządkowali sobie większość regionów Azji Centralnej, w tym Balk, Bucharę i Ferganę.

Merw odzyskało swoje wielkie znaczenie, gdy w 748 roku Abu Muslim ogłosił w tym mieście powstanie nowej dynastii: abbasydzkiej. Miasto przeobraziło się w centrum opozycji przeciw kalifatowi Ummajjadów. Nawet gdy już Abbasydzi osiedlili się w Bagdadzie, Abu Muslim był w Merw na wpół niezależnym władcą. Miasto stale stanowiło bazę dla zwolenników Abbasydów podczas rewolucji abbasydzkiej (746-750), a później źródło wsparcia politycznego dla abbasydzkich władców w Bagdadzie. Potomek Proroka, Muhammad - ósmy imam szyickich dwunastowców - Ali ibn Musa al-Ridha (766-818, znany też jako Reza albo Abu al-Hasan) przeniósł się do Merw i mieszkał tam wiele lat. Merw było również ośrodkiem ruchu skupionego wokół al-Muqanny, czyli „Zasłoniętego Proroka" (zm. 783), który zyskał wielu zwolenników twierdząc, że jest wcieleniem Boga. W latach 813-818 okresowa siedziba kalifa al-Mamuna uczyniła Merw stolicą islamskiego świata. Gubernator prowincji Chorasan, rezydujący w Merw, był zawsze jedną z kluczowych postaci politycznych w kalifacie. Wpływowa rodzina Barmakidów ${ }^{18} \mathrm{z}$ Merw odegrała istotną rolę w przekazaniu światu arabskiemu, a w dalszej kolejności również innym cywilizacjom greckiej wiedzy.

Gdy kalifat osłabł, w 821 roku arabskie rządy w Merw zostały zastąpione przez dynastię Tahiridów. Rządzili oni Merw do roku 873. Po nich nastąpili Saffarydzi, następnie Samanidzi i Ghaznawidowie. W 1037 roku turkmeńscy Seldżukowie, klan tureckich Oguzów, przemieszczając się ze stepów na wschód od Morza Aralskiego, pokojowo przejęli Merw. Posiadłości Seldżuków w Chorasanie powiększały się i Merw stało się naturalną stolicą seldżuckich sułtanów.

${ }^{16}$ Dla zoroastryjczyków Merw (Mouru) było jednym z szesnastu doskonałych miejsc stworzonych przez boga Ahura Mazdę.

${ }^{17}$ S. McDonough, A Second Constantine? The Sasanian King Yazdgard in Christian History and Historiography. ,Journal of Late Antiquity” 1 (2008) nr 1, s. 127-140.

${ }^{18}$ Barmakidzi pierwotnie odziedziczyli tradycję liderów buddyjskich (monaster Mawbahar w Balk). Urośli w znaczenie w czasach abbasydzkich. Khalid, syn Barmaka, został wezyrem pierwszego kalifa dynastii abbasydzkiej. Jego syn Yahya pomógł Harunowi Al-Rashidowi w zdobyciu tronu i stał się najbardziej wpływowym człowiekiem kalifatu. Barmakidzi byli znani ze swego splendoru i gościnności. Są wspominani w niektórych historiach Tysiąca i jednej nocy. 
Pod koniec XI wieku przeobraziło się we wschodnią stolicę podzielonego państwa Seldżuków, jednak od 1118 roku ponownie pełniło funkcję stolicy całego imperium. Chaghri oraz jego syn Alp Arslan i prawnuk Ahmad Sanjar zostali pochowani w Merw. Panowanie Sanjara, naznaczone konfliktami z Karachitajami i Chorezmijczykami, zakończyło się w 1153 roku, gdy turkmeńscy koczownicy zza Amu-Darii splądrowali miasto. Merw znowu zmieniało zarządców: byli nimi Chorezmijczycy, turkmeńscy nomadowie i Gurydamowie.

W 1221 roku miasto otworzyło swe bramy przed nadchodzącą armią mongolską, co jednak nie uchroniło Merw od zniszczenia. Zapiski historyczne podają, iż całą ludność (w tym uchodźców), liczącą wtedy około miliona osób, zmasakrowano: było to jedno z najbardziej krwawych ludobójstw w świecie. Historyk napisał, że Czyngis-chan rozkazał, zasiadłszy na złotym tronie, by przyprowadzono przed jego oblicze żołnierzy, po czym kazał wszystkich stracić. Następnie nakazał bić i torturować w okrutny sposób pozostałych mieszkańców Merw w celu pozyskania od nich bogactw. Potem kazał spalić miasto. Po tej masakrze policzono zwłoki. Miało ich być około 700 tysięcy. Mimo iż później miasto częściowo odbudowano, nigdy nie odzyskało ono swego dawnego blasku.

Inwazja Mongołów oznaczała koniec potęgi Merw na ponad sto lat. $\mathrm{Na}$ początku XIV wieku miasto stało się jednak ponownie stolicą metropolity Kościoła wschodniego: pod panowaniem Kartydów. Później znalazło się pod rządami Uzbeków, Persów z dynastii safawidzkiej. W latach 1788-1789 ostatecznie zrównano je z ziemią, a ludność deportowano. W 1999 roku UNESCO umieściło Merw na liście światowego dziedzictwa.

Jednak w XII-XIII wieku Merw, znane wtedy jako „Wielkie Merw” (Marw Al-Shāhijān), było prawdopodobnie największym miastem świata, wyprzedzającym takie metropolie, jak Konstantynopol czy Bagdad. Nazywano je wręcz „Matką świata” i „Stolicą wschodniego świata islamu”. Mogło liczyć wtedy około pół miliona mieszkańców. Merw stanowiło centrum nauki i kultury, przyciągające znanych poetów, muzyków, lekarzy, matematyków i astronomów. Wielki perski matematyk, astronom, filozof i poeta Omar Khayyam pracował przez wiele lat w tutejszym obserwatorium. Geograf arabski Jaqut al-Hamawi naliczył aż dziesięć wielkich bibliotek w Merw, w tym największą - zawierającą 12 tysięcy woluminów - przy głównym meczecie ${ }^{19}$.

Merw rozsławiło się tkaninami cechującymi się wysoką jakością. Dwunastowieczny, arabski geograf al-Idrisi zanotowal, że z tego kraju pochodzi sporo jedwabiu i bawełny najwyższej jakości, nazywanej bawełną merwiańską - niezwykle delikatną i miękką. Eleganckie stroje i jedwabne turbany z Merw podziwiano w całym islamskim świecie. Merw kojarzono też ze słynnymi melonami.

19 Por. A.Yu. Yakubovskii, C.E. Bosworth, Marw al-Shahidjan, w: Encyclopédie de l'Islam, t. VI, Leiden-Paris 1991, s. 603-606. 
Ponadto miasto do takiego stopnia znane było z licznych uczonych, iż pojawiło się określenie: Marwazi (po persku, al-Marwazi po arabsku), oznaczające: „pochodzący z Merw”. Wśród muzułmańskich uczonych i twórców taki przydomek w IX wieku nosili między innymi: 'Īsā al-Marwazī (syryjski leksykograf), Habash al-Hasib al-Marwazi (perski astronom, geograf i matematyk - opisał stosunki trygonometryczne), Abū Muhammad Abd-Allāh ibn Muslim ibn Qutayba al-Dīnawarī al-Marwazī (uczony muzułmański), Abu'l-Abbas Marwazi (perski poeta), Abdallah ibn Muhammad ibn Yazdad al-Marwazi (wyższy urzędnik perski na dworze kalifatu Abbasydów) oraz Yusuf ibn Muhammad ibn Yusuf al-Marwazi (gubernator za czasów kalifatu Abbasydów). W X-XII wieku taki przydomek otrzymali między innymi: Kisai Marvazi (perski poeta), Abu Tahir Marwazi (prominentny perski filozof), Sharaf al-Zaman al-Marwazi (lekarz i autor dzieła Natura zwierzat) $)^{20}$.

Wśród chrześcijańskich teologów z Merw najbardziej znany jest Iszodad. Przydomek „z Merw” świadczy o jego pochodzeniu. Był biskupem Hdatta (obecnie północny Irak) i poważnym kandydatem na patriarchę w Bagdadzie około roku 850. W swoich pracach czerpał obficie z autorów greckich i syryjskich. Ponad sto lat temu, w latach 1911-1916, ukazało się pierwsze współczesne opracowanie i tłumaczenie dzieł Iszodada, bazujące na trzech wtedy dostępnych manuskryptach ${ }^{21}$. Studia nad syryjską tradycją chrześcijańską, w tym nad Iszodadem, bardzo się rozwijają. W latach pięćdziesiątych XX wieku wiele prac jemu poświęconych napisał Jacques-Marie Vosté. Z ostatnich lat wspomnieć można przynajmniej jedną dostępną pozycję w Internecie i zawierające bardzo dobre dane bibliograficzne ${ }^{22}$. Wśród polskich autorów wymienić należy Andrzeja Uciechę i jego prace ${ }^{23}$.

\section{Kontekst buddyjski}

Nie będziemy odwoływać się tutaj do kontekstu zaratusztrianizmu i manicheizmu, które również były tam obecne, ale pokrótce trzeba wspomnieć o buddy-

${ }^{20}$ Szerzej o muzułmańskiej nauce w Merw tego okresu: M. Can, Emergence of Islamic Sciences in Merv (First Two Centuries A.H.), „Mütefekkir” 3 (2016) nr 6, s. 399-425. Jest to tekst po turecku, ale posiada streszczenie po angielsku i właściwą bibliografię.

${ }^{21}$ The Commentaries of Isho 'dad of Merv, Bishop of Hadatta (c. 850 A.D.) in Syriac and English, thum. i red. M.D. Gibson, t. I-V, Cambridge 1911-1916.

${ }^{22}$ C. Hoogerwerf, Historische versus allegorische uitleg in de inleiding van Išo 'dad van Mervs commentaar op de Psalmen: Vertaling en bronkritische analyse, „NTT Journal for Theology and the Study of Religion" 73 (2019) nr 4, s. 283-297.

${ }^{23}$ Por. A. Uciecha, Adam i Ewa we wschodnio-syryjskiej egzegezie Iszodada z Merw (Rdz 2,21-24): stan badań, komentarz i przekład, „Śląskie Studia Historyczno-Teologiczne” (2016) z. 2, s. 302-310; tenże, Egzegeza biblijna w komentarzach syryjskich Afrahata, Efrema, Iszodada z Merw i Teodora Bar Koni: zarys problematyki, „Vox Patrum” 67 (2017), s. 673-686. 
zmie jako bezpośrednim, przedchrześcijańskim kontekście religijnym ${ }^{24}$. Buddyzm dotarł do Azji Centralnej z północnego zachodu subkontynentu indyjskiego. Jego rozprzestrzenianie się na terenach dzisiejszego Afganistanu musiało rozpocząc się nie później niż w III wieku przed Chr., gdy indyjskiej dynastii Maurjów, a zwłaszcza władcy Aśoce (ok. 268-233 przed Chr.), udało się zjednoczyć większość terenów Indii i napierać na północno-zachodnią granicę imperium do Kabulu i Kandaharu w dzisiejszym Afganistanie. Ten rozwój jest dobrze udokumentowany w słynnych, kamiennych napisach umieszczonych przez Aśokę w różnych częściach imperium. Pod jego panowaniem rozpoczął się rozwój buddyzmu, który z ruchu ascetycznego, zapoczątkowanego w północno-wschodnich Indiach, stał się religią uniwersalną. Stabilność polityczna, osiągnięta przez dynastię Maurjów, faworyzowała rozprzestrzenianie się buddyzmu, zwłaszcza wzdłuż tras handlowych. Później władca Kaniszka Wielki (1. połowa II w. po Chr.), najważniejszy władca dynastii Kuszanów, bywał tytułowany „podporą buddyzmu”.

Połączenie koncepcji grecko-rzymskich z indyjskimi przez artystów w Kandaharze stworzyło charakterystyczny styl, który wpłynął na sztukę indyjską i stał się modelem sztuki buddyjskiej w Azji Centralnej i Wschodniej. Grecy mieszkali w Baktrii i Kandaharze, począwszy od indyjskiej kampanii Aleksandra Wielkiego w IV wieku przed Chr.

W okresie swego maksymalnego rozprzestrzeniania buddyzm stał się głównym zwornikiem religijnym i kulturowym nie tylko w Indiach, w Azji Wschodniej i Południowo-Wschodniej, ale również w Afganistanie i na dużych połaciach Azji Centralnej. Dotarł też do Merw w dzisiejszym Turkmenistanie, do Termezu na pograniczu Uzbekistanu i Afganistanu, a także do Kurgonteppa w południowym Tadżykistanie. Mimo iż źródła pisane ${ }^{25} \mathrm{i}$ wykopaliska archeologiczne świadczą o jego obecności nawet dalej na północy, na przykład w Samarkandzie, w Quva niedaleko Fergany, w Aq Besim w pobliżu Biszkeku, to na tych obszarach nie zdobył popularności. Pozostały po nim jednak takie imponujące zabytki jak pochodzące z VI wieku kamienne posągi stojącego Buddy w Bamianie ${ }^{26}$ czy duże klasztory w jaskiniach, na przykład w Dunhuang z bogactwem fascynujących obrazów ściennych, które świadczą o dawnej świetności i znaczeniu buddyzmu ${ }^{27}$.

${ }^{24}$ Por. J.U. Hartmann, Buddhism in Central Asia, w: Encyclopedia of Religion, t. II, Detroit 2005, s. 1144-1148.

${ }^{25} \mathrm{Na}$ przykład opisy podróży pielgrzymów, takich jak: Faxian w V wieku, Xuanzang (VII), Huizhao (VIII). Por. M. Deeg, Chinese Buddhists in Search of Authenticity in the Dharma, ,, The Eastern Buddhist" 45 (2014) nr 1-2, s. 11-22.

${ }^{26}$ Najwyższa figura miała $53 \mathrm{~m}$ i była największym na świecie wyobrażeniem Buddy. W 2001 roku zostały zniszczone przez talibów.

27 Por. H.J. Klimkeit, Buddhism in Turkish Central Asia, „Numen” 37 (1990), s. 53-69; J. Nattier, Church Language and Vernacular Language in Central Asian Buddhism, „Numen” 37 (1990), s. 195- 


\section{Kontekst chrześcijański}

Wiara chrześcijańska w Azji Centralnej zaczęła rozwijać się przynajmniej od III wieku. Niektórzy chrześcijanie uciekali tam w czasie prześladowań. Merw miało już swego biskupa w 334 roku. W V wieku znajdujemy wzmianki o chrześcijańskim biskupie w Herat, a Samarkanda w XI wieku była już metropolią (biskup pojawił się o wiele wcześniej). Te trzy siedziby stały się metropoliami, a to oznaczało również podporządkowane im diecezje, czyli miliony chrześcijan. Erica C.D. Hunter zebrała szczegółowe informacje na temat siedzib biskupich w Azji Centralnej w interesującym nas okresie, w prowincjach Chorasanu (m.in. Merw, Herat, Niszapur), Chorezmu-Sogdiany (znane również z podróży Wilhelma z Rubruk), Gorganu (obecnie prowincja i miasto w północnym Iranie), Transoksanii (np. Buchary i Samarkandy) i Turkiestanu (dzisiaj zachodnie Chiny, m.in. Kaszgar) ${ }^{28}$.

Kościoły Azji pierwszych wieków były bardzo misyjne. Trzeba o tym pamiętać w kontekście historycznym. W Europie dopiero w połowie VI wieku św. Benedykt zakłada klasztor na Monte Cassino, a Merw jest znanym centrum misyjnym już w IV stuleciu. Wyruszają z niego wyprawy misyjne do takich miast i osiedli Azji Centralnej jak Buchara czy Samarkanda. Przed końcem V wieku chrześcijańscy misjonarze ${ }^{29}$ pracowali wśród Hunów i Turków Azji Centralnej. Gdy na przykład perski władca Kawad I uciekał do Azji Centralnej w 499 roku, napotkał na swej drodze grupę chrześcijańskich misjonarzy: biskupa, czterech prezbiterów i czterech świeckich, udającą się w te regiony, by głosić Turkom Ewangelię. Mamy też informację, że w 549 roku na prośbę heftalickich Hunów żyjących po obu stronach Oxusu patriarcha Seleucji-Ktezyfonu posłał biskupa dla chrześcijan tego regionu ${ }^{30}$.

-219; D.A. Utz, A Survey of Buddhist Sogdian Studies, Tokyo 1978; L. Sander, Buddhist Literature in Central Asia, w: Encyclopaedia of Buddhism, red. G. P. Malalasekera, t. IV, Colombo 1979, s. 52-75.

${ }^{28}$ E.C.D. Hunter, Syriac Christianity in Central Asia, „Zeitschrift für Religions- und Geistesgeschichte" 44 (1992), s. 362-368; M.A.L. Comneno, Nestorianism in Central Asia during the First Millennium: Archaeological Evidence, „Journal of the Assyrian Academic Society” 11 (1997), s. 20-53 (z bardzo dobrą bibliografia)); C.A. Panchenko, Orthodoxy and Islam in the Middle East. The Seventh to the Sixteenth Century, Jordanville 2021; P. Wood, The Chronicle of Seert: Christian Historical Imagination in Late Antique Iraq, Oxford 2013; P. Nautin, L'auteur de la "Chronique anonyme de Guidi”: Élie de Merw, „Revue de l'histoire des religions” 199 (1982) nr 3, s. 303-314.

${ }^{29}$ W VI wieku do głównego Kościoła „nestoriańskiego” dołączył ,jakobicki”. Gdy cesarze prześladowali monofizytów, wielu z nich uciekało za granicę. Dwóch monofizyckich biskupów zostało konsekrowanych dla arabskich chrześcijan. Jeden z nich, Jakub Baradeusz, wniósł wiele nowej „krwi” do tej tradycji. Dzisiaj słowo ,jakobici” bywa do niego odnoszone, ale pierwotnie używano go w odniesieniu do Jakuba apostoła, czyli wierności samemu Jezusowi Chrystusowi. Nie było ich tak wielu jak ,nestorian”, ale także mieli swoich biskupów i misjonarzy w Azji Centralnej. W XI wieku kalifowie podporządkowali ich, i melkitów, władzy katolikosów nestoriańskich.

${ }^{30}$ T.V. Philip, The Missionary Impulse in the Early Asian Christian Traditions, s. 509. 
Zachowały się również relacje o wielkiej liczbie nawróconych nad rzeką Oksus na skutek wysiłków podejmowanych przez Eliasza, metropolitę Merw w VII wieku. Stopniowo i Samarkanda stawała się ważnym centrum chrześcijańskim i podstawą ekspansji misyjnej dalej na wschód. Działalność misyjna chrześcijan orientalnych sięgała dalej na północny wschód, w kierunku jeziora Bajkał. W X i XI stuleciu rozmaite plemiona tatarskie były całkowicie lub w dużym stopniu chrześcijańskie, zwłaszcza Keraici, Ujgurowie, Naimańczycy i Merkici ${ }^{31}$. Poza działalnością chrześcijańskich misjonarzy sensu stricto, wpływy chrześcijańskie rozpowszechniały się za pośrednictwem chrześcijańskich lekarzy, pisarzy i rzemieślników, którzy łatwo znajdowali zatrudnienie wśród Turków i Hunów.

Zasięg ich działalności ewangelizacyjnej nie ograniczał się tylko do Azji Centralnej i Syberii. Z lat 520-525 mamy świadectwa o obecności chrześcijan z Kościołów orientalnych na Sokotrze, w południowo-zachodnich i centralnych Indiach, na Sri Lance, w Pege (południowa Birma-Mianma), w Cochinie (południowy Wietnam), Syjamie (Tajlandia) i Tonkinie (północny Wietnam). Do dzisiaj istnieją również napisy, krzyże, freski i ruiny oraz współczesne dokumenty dowodzące obecności chrześcijan w tych miejscach od VII do XV wieku ${ }^{32}$.

Chrześcijanie Azji Centralnej zawsze interesowali się Chinami. Wiemy, że już w 550 roku mnisi chrześcijańscy przemycali jedwabniki z Serindy (Chin) do Cesarstwa Bizantyńskiego. Skoro wtedy mieszkali już „długo” w Serindzie, to oznacza, że musieli tam być przynajmniej w V wieku. Wiemy o oficjalnej misji z 635 roku, kiedy to misjonarze dotarli do chińskiej stolicy cesarstwa Ch'ang-an, rozpoczynając misję trwającą ponad dwieście lat. Przybyli do Chin w początkach panowania nowej dynastii Tang, gdy rodzima polityka była dość otwarta na nowe trendy myślowe.

Znowu warto odnieść się do historii Europy. Gdy pod koniec VIII wieku w Europie dominowała wizja Karola Wielkiego: „chrzest albo miecz”, w tym samym czasie bardzo otwarty misyjnie patriarcha Seleucji-Ktezyfontu Tymoteusz w 781 roku twierdził, że władca pewnego plemienia Turków, który miał rządzić dużą częścią Azji Centralnej, został chrześcijaninem i że on (Tymoteusz) mianował dla nich metropolitę. Pisał, iż „Duch Święty namaścił metropolitę dla Turków, a my przygotowujemy się do wyświęcenia kolejnego dla Tybetańczyków"33. Tymoteusz posyłał biskupów, którzy zdobywali dla wiary wiele ludów żyjących na południe i wschód od Morza Kaspijskiego ${ }^{34}$. Gdy do patriarchy dotarły wiadomości o ich

31 Tamże.

32 Tamże, s. 510.

${ }_{33}$ P. Jenkins, The Lost History of Christianity. The Thousand-Year Golden Age of the Church in the Middle East, Africa, and Asia - and How It Died, New York 2008, s. 11 (thum. W. Kluj).

${ }^{34}$ Jeden z nich, niejaki Shubhal-ishu, podobnie jak później w Europie święci Bonifacy czy Otton z Bambergu, przybył z wielką pompą, żeby wywrzeć wrażenie na „barbarzyńcach”, głosił Ewangelię, chrzcił, budował kościoły, a jak trzeba było, to i ściął święte drzewo. 
sukcesach, Tymoteusz mianował dwóch nowych metropolitów w tym regionie. Zlecał także mnichom niesienie wiary nad brzegi Morza Kaspijskiego i do Chin ${ }^{35}$.

Mogło więc wydawać się, że chrześcijaństwo stanie się dominującą religią w Azji Centralnej, jednak w VIII wieku przybył konkurent. Islam zaczął coraz bardziej przenikać do tego regionu, wpierw militarnie.

\section{Islamski kontekst religijny}

Początkowo Arabowie w Azji Centralnej narzucali islam siłą. Później jednak przyjęli bardziej umiarkowane podejście do islamizacji regionu ${ }^{36}$. Formą wiary muzułmańskiej, najczęściej praktykowaną w tej części Azji Środkowej, był początkowo sunnizm w wersji hanafickiej. Środkowoazjatyccy uczeni podróżowali po całym świecie muzułmańskim. Wywarli znaczny wpływ na rozwój nauk stosowanych i teoretycznych, a także na islamską filozofię. Spośród najbardziej znanych uczonych, pochodzących z Azji Centralnej, można wymienić takie nazwiska jak: Al-Chuwarizmi (780-850) ${ }^{37}$, Al-Farghani $(805-870)^{38}$, Al-Buhari (810-887) ${ }^{39}$, At-Tirmizi $(824-892)^{40}$, At-Tabari $(838-923)^{41}$, Al-Farabi $(870-950)^{42}$, Al-Biruni (973-1048) ${ }^{43}$, Awicenna - Ibn Sina (980-1037) ${ }^{44}$ czy Nasir-

${ }^{35}$ Tymoteusz przewodził 19 metropolitom i 85 biskupom. Misyjny rozmach Kościoła kierowanego przez niego sprawiał, że mógł on tworzyć nowe metropolie w Rai koło Teheranu oraz w Syrii, Turkiestanie, Armenii i nad Morzem Kaspijskim. Arabia miała już co najmniej cztery biskupstwa (Tymoteusz stworzył nowe na terenie dzisiejszego Jemenu). Kościół stale rozrastał się w południowych Indiach, a były to już czasy państwa islamskiego, półtora wieku po Mahomecie.

${ }^{36}$ Ogólnie: S. Akiner, Islam in Central Asia, w: Encyclopedia of Religion, t. VII, Detroit 2005, s. 4620-4630; M. Dillon, Islam in China, w: tamże, s. 4630-4640.

${ }^{37}$ Spopularyzował dziesiętny system liczenia, pojęcie zera, ułamków oraz funkcji: sinus i tangens. Termin algebra pochodzi od tytułu jego dzieła, a termin algorytm od zniekształconej wersji jego przydomka.

38 Jeden z najsłynniejszych astronomów. Do jego dzieła Elementy astronomii ruchów niebieskich i kalkulacji odwoływali się zarówno Mikołaj Kopernik w swych obliczeniach średnicy ziemi, jak i Krzysztof Kolumb w swojej podróży do Ameryki.

${ }^{39}$ Kompilator jednego z podstawowych zbiorów Tradycji Proroka. Po polsku: S. Al-Buchari, Zbiór wiarygodnych hadisów Proroka Muhammada, tłum. P. Ziółkowski, Poznań 2018.

${ }^{40}$ Autor jednej z sześciu kanonicznych kompilacji hadisów w islamie sunnickim.

${ }^{41}$ Autor między innymi wielotomowej historii powszechnej świata muzułmańskiego oraz słynnego komentarza do Koranu.

${ }^{42}$ „Drugi Nauczyciel” filozofii islamskiej (pierwszym był Arystoteles). Lista jego dzieł obejmuje 191 pozycji. Dążył do pogodzenia filozofii Arystotelesa i Platona z islamem. Jego nauczycielem był słynny chrześcijański lekarz, filozof i komentator Arystotelesa - Abu Biszr Matta ibn Junus.

${ }^{43}$ Znany historyk okresu Sasanidów. Po 1017 roku wyjechał do Indii i tam podjął wszechstronne studia nad tamtejszą kulturą.

${ }^{44}$ Wielki filozof. W swej metafizyce świat pojmował teocentrycznie, ale inaczej niż chrześcijanie. Świat był, według niego, stworzony z myśli Bożej, nie z woli Bożej, i to stworzony z materii 
-Khusraw (1004-1046) ${ }^{45}$. Patrząc na wielki rozwój myśli muzułmańskiej w tej części Azji, warto pamiętać, że są to wieki IX-XI, czyli czas początków państwa polskiego, a nawet trochę wcześniejszy. Było wielu tych uczonych. Marek M. Dziekan w swojej książce wspomina ponadto takich znanych pisarzy muzułmańskich tego okresu z Azji Centralnej, związanych z Niszapur, Bucharą czy Samarkandą, jak: Ad-Darimi (797-869), Abu Mansur Al-Maturidi (853-944), Al-Kalabazi (zm. 990/994), An-Nasafi (zm. 943), As-Sulami (937-1021), Al-Dżuwajni (1028-1085), Asz-Szahrastani (1076-1153) czy Cziszti (1141-1236) ${ }^{46}$.

Oczywiście Merw był bardzo ważnym centrum myśli muzułmańskiej, ale nie jedynym. O roli Samarkandy jako ośrodka myśli muzułmańskiej świadczy na przykład przydomek: Al-Samarqandi, nadawany osobom związanym z tym miastem. W IX wieku byli to między innymi: Abd Allāh ibn 'Abd ar-Raḥmān ad-Dārimi as-Samarqandī znany jako al-Darimi (uczony i imam) oraz Abu Bakr al-Samarqandi (sunnicko-hanaficki teolog). W X wieku, poza wyżej wspomnianym Maturidim, ten tytuł nadano między innymi takim osobom, jak: Al-Hakim al-Samarqandi (uczeń Maturidiego i qadi Samarkandy) oraz Abu al-Layth al-Samarqandi (uczony hanaficki). W XII wieku byli to na przykład: Nizami Aruzi Samarqandi (perski poeta i pisarz), Suzani Samarqandi (perski poeta) oraz Fatima al-Samarqandi (uczona i prawniczka, osobista doradczyni Nur ad-Dina, mentora Saladyna, pierwszego sułtana Egiptu i Syrii). W XIII wieku do tej grupy zaliczały się między innymi takie osoby jak: Najib ad-Din Samarqandi (znany lekarz), Athir al-Din al-Abhari al-Samaqandi (filozof, astronom, astrolog i matematyk) i Shams al-Din al-Samarqandi (teolog hanaficki tradycji maturidyjskiej, astronom i matematyk), a w XV wieku - Abd-al-Razzāq Samarqandī (uczony muzułmański i kronikarz Timurydów) $)^{47}$.

Islam w Azji Centralnej miał wielu wybitnych przedstawicieli w tym okresie, ale decydującą rolę w jego indygenizacji odegrał sufizm, czyli mistyczna tradycja islamu. Niektórzy dopatrują się tutaj wpływu tradycji mnichów chrześcijańskich lub buddyjskich. Pierwsze centra sufickie Azji Centralnej pojawiły się w Balch ${ }^{48}$ i Niszapur w VIII i IX wieku. Później dołączyły do nich również

pierwszej, a nie z nicości. Jego traktat medyczny wywarł wielki wpływ na średniowieczną medycynę.

${ }^{45}$ Sekretarz emira Chorasanu w Merw. Do dzisiaj czytane są jego opisy podróży. Porzucił życie w luksusie i wyruszył w ubogą pielgrzymkę do Mekki i Medyny.

${ }^{46}$ M.M. Dziekan, Pisarze muzulmańscy VII-XX w. Mały słownik, Warszawa 2003, strony (odpowiednio): 37, 86, 74, 94, 106, 41-42, 108, 35-36.

${ }^{47}$ S. Akiner, Islam in Central Asia, s. 4620-4630. O islamie na terenach chińskich: por. W. Cieciura, Muzutmanie chińscy. Historia, religia, tożsamość, Warszawa 2014, s. 30-78, zwłaszcza s. 30-53.

${ }^{48}$ Najbardziej znanym, sufickim mistykiem i założycielem bractwa „wirujących derwiszy” (maulawijja), pochodzącym z ośrodka w Balchu, był Rumi (1207-1273). 
Merw, Buchara, Chorezm i inne. Pierwszymi uczniami byli adepci bagdadzkiej szkoły mistyków. Rodzime bractwa sufickie (tarikaty) zaczęły się pojawiać w Azji Centralnej pod koniec XII stulecia. Wywierały one duży wpływ wśród zwykłych muzułmanów, z jednej strony proponując nawiązanie bezpośredniego kontaktu z Bogiem, a z drugiej nie zwracając uwagi na różnice w pozycji społecznej. Czasami stawały się one wyrazicielami pewnych interesów rozmaitych grup oraz także centrami ruchów politycznych ${ }^{49}$.

Główną postacią pierwszego okresu rozwoju sufizmu centralno-azjatyckiego był Jusuf Hamdani (1048-1141). Po pobycie w najważniejszych centrach Bliskiego Wschodu przeniósł się do Azji Centralnej i tam spędził większość swojego życia. Założył między innymi khanqah (monaster suficki) w Merw, znany jako „Al-Kaba Chorasanu”. Od niego wywodzą się dwa tarikaty (bractwa muzułmańskie). Pierwszy rozwinął Ahmad Jasavi (1106-1166 - tarikat jasavijja), drugi Bah Ad-Din An-Nakszbandi (1318-1389 - tarikat nakszbandijja). Oba te „zakony” sięgnęły daleko poza granice Azji Środkowej. Pierwszy przyciągał zwolenników głównie w świecie tureckojęzycznym, a drugi rozprzestrzenił się w Indiach, Chinach, a później i w Imperium Osmańskim. Nie było między nimi sztywnej granicy. Dwa inne wielkie muzułmańskie „zakony misyjne” w Azji Środkowej to: kubrawici (Najm al-Din al-Kubra, 1145-1221) i kadyryci (Abd al-Qadir Gilani, 1078-1166) ${ }^{50}$.

Ze względu na polityczne oddziaływanie najbardziej wpływową ścieżką suficką w Azji Środkowej był tarikat nakszbandijja. To właśnie on odegrał kluczową rolę w konwersji Mongołów na islam. Ponieważ chanowie mongolscy zostali władcami nie tylko Transoksanii, ale objęli przywództwo plemiennych konfederacji stepowych, nakszbandijja zyskała uprzywilejowaną pozycję zarówno wśród ludności osiadłej, jak i nomadów. Umocnili oni swoją pozycję przy Timurze, który sam miał być uczniem tej szkoły ${ }^{51}$. Nakszbandijja ma wiele odłamów. Elementem odróżniającym tę szkołę od innych tarikatów jest cicha modlitwa (zikr). Uczniowie owej szkoły modlą się w ciszy, przekonani, że osiąga się w ten sposób silniejszy związek z Bogiem. Praktyki modlitewne nakszbandijji odbywają się często bez świątyń. Niejednokrotnie uczniowie, siedząc w kręgu lub pojedynczo, szepczą słowa modlitwy do momentu osiągnięcia ekstazy. Ta

49 Tarikatem, który przekształcił się w organizację polityczną, a potem wręcz w państwo, był safawijja, stanowiący właściwie konfederację kilku, a następnie kilkunastu plemion turkmeńskich. Siódmy szajch, Ismail, podbił Iran i założył dynastię Safawidów.

${ }^{50}$ Szerzej: M. Brill Olcott, Sufism in Central Asia. A Force for Moderation or a Cause of Politicization?, „Carnegie Papers” nr 84.

${ }^{51}$ Timur okazywał również oznaki przychylności tradycji jasavi, wznosząc mauzoleum nad grobem Jasaviego. Późniejsi duchowi przywódcy ze szkoły jasavi wpływali silnie na chanów i sułtanów. O jego wielkim znaczeniu do dzisiaj może świadczyć fakt, że rok 2016 został przez UNESCO ogłoszony rokiem Jasaviego z okazji 850-lecia jego śmierci. 
cecha dobrze trafiała do mentalności ludów koczowniczych, niemających stałych miejsc pobytu. Nakszbandijja zrodziła się w Persji, jednak najwięcej zwolenników zyskała w Azji Centralnej i Turcji. Główny ośrodek tariki nakszbandijjskiej znajdował się w Bucharze. Było to największe centrum nauki islamu w środkowej Azji. W odróżnieniu od innych bractw sufickich, członkowie tariki nakszbandijjskiej uznają działalność misjonarską i aktywność polityczną za ważną część swej drogi ${ }^{52}$.

Dargah (miejsce pochówku, świątynia grobu) znanych liderów religijnych, zwłaszcza sufickich, i pielgrzymki do tych miejsc charakteryzują islam centralno-azjatycki. Grób Nakszbandiego znajduje się niedaleko Buchary i pozostaje do dzisiaj najważniejszym celem pielgrzymek w Azji Centralnej. Być może jest to konsekwencja chrześcijańskiego kultu świętych ${ }^{53}$.

\section{Decydujące „starcie”}

Przez kilka stuleci Merw stanowiło jeden z największych ośrodków chrześcijańskich w Azji Centralnej i w świecie. Od V wieku było idealną bazą dla wypraw misyjnych na wschód, do tureckich plemion środkowej Azji i dalej aż do Chin i Syberii. Chrześcijańscy uczeni z Merw tłumaczyli podstawowe dzieła z języka greckiego i syryjskiego na języki Azji Środkowej i Wschodniej. Poza mnichami i duchowieństwem nieformalnymi misjonarzami byli podróżujący kupcy ${ }^{54}$. Mimo iż od VII wieku Merw znajdowało się pod rządami muzułmanów, to jednak wspólnota chrześcijan stale w nim istniała i rozwijała się (wspólnie $\mathrm{z}$ buddystami, zaratusztrianami i manichejczykami). Od VIII wieku Merw stało się „punktem wyjścia” dla muzułmańskiej ekspansji w Azji Centralnej. Chrześcijanie musieli zachowywać najwyższe standardy z powodu stałej konkurencji. Kościoły Azji Centralnej nieustannie tkwiły w korzeniach judeochrześcijańskich

${ }^{52}$ Wielu jej członków stało na czele powstań przeciwko władzy carskiej i komunistycznej na ziemiach byłych republik ZSRR w Azji Centralnej. Tarika nakszbandijjska była głównym organizatorem religijnej i antykolonialnej walki na północnym Kaukazie. Współcześnie bractwo jest szczególnie aktywne w: Turcji, Afganistanie, Czeczenii, Dagestanie, Tadżykistanie, Kurdystanie, Syrii, Egipcie, Palestynie, Indiach, Indonezji, Malezji, Chinach. Jest też drugim co do wielkości bractwem wśród Kurdów. Por. Z. Landowski, Sufizm. Podstawowe informacje, Warszawa 2010, s. $178-191$.

${ }_{53}$ Por. P. Jessa, ,Przyjaciele Allaha”. Kult muzulmańskich świętych w Azji Środkowej, Poznań 2009; Muslim Saints and Mystics. Episodes from the Memorial of the Saints by Farid al-Din Attar, Ames 2000; M. Maciak, Muzulmańskie pielgrzymowanie w krajach Azji Centralnej (rozprawa doktorska na UKSW), Warszawa 2018.

${ }^{54}$ Wtedy językiem komunikacyjnym był tam język sogdyjski, który wspominali (musieli o nim wiedzieć) święci Cyryl i Metody w swej słynnej dyspucie weneckiej, dotyczącej dopuszczania innych języków w liturgii (poza hebrajskim, greką i łaciną). 
i syryjskich. Chrześcijanie żyli nie pod władzą chrześcijańskiego króla (jak w Europie), lecz jako jedynie tolerowana, choć dość aktywna, mniejszość. Był to Kościół w społeczeństwie międzyreligijnym.

Pamiętając, że Konstantynopol miał wtedy nieustannie (do 1453) chrześcijańskich władców, trudno się dziwić, że chrześcijanie w Azji mogli snuć podobne plany. Marzeniem wszystkich misjonarzy było nawrócenie króla lub klasy rządzącej, która następnie wprowadziłaby do Kościoła całe państwo. Chrześcijanie Wschodu „zdobywali” dla Ewangelii pewne plemiona, ale nie były to wielkie i stabilne państwa, jak to stało się w przypadku Karola Wielkiego i Kościoła łacińskiego w Europie. Kościół Wschodu zyskał przyczółek wśród kilku ważnych nacji, w tym Ujgurów i Turków Ongutów. Największy „triumf” miał miejsce około 1000 roku, kiedy to władca Turków keraickich ${ }^{55}$ (nad brzegiem jeziora Bajkał) przyjął wiarę, jaką głosili w jego królestwie chrześcijańscy kupcy, pochodzący prawdopodobnie z Merw. Miał wprowadzić za sobą do Kościoła ponad 200 tysięcy swoich poddanych. Wśród Keraitów chrześcijanie byli obecni przez około cztery stulecia. Turcy keraiccy nie stworzyli jednak trwałego państwa. Udało się to innym Turkom - seldżuckim, którzy później podbili znaczną część Cesarstwa Bizantyjskiego, oraz synom Osmana, którzy założyli rozległe imperium osmańskie. Te grupy jednak przyjęły islam.

Merw było stale aktywnym centrum chrześcijańskiej ekspansji misyjnej (poza obszarami, którymi rządzili władcy muzułmańscy) w świecie multireligijnym. Sam fakt dominacji politycznej muzułmanów, mimo iż prowadził do rozmaitych utrudnień, to jednak nie przekreślał chrześcijańskiej obecności. Przyznają to nawet autorzy muzułmańscy. Arabski kronikarz al-Biruni (zm. 1048) pisze o św. Janie z Merw, zabitym przez muzułmanów za wiarę i wspominanym przez chrześcijan Chorezmu w dniu 14 lipca, natomiast al-Tabari podaje informację o chrześcijańskim pogrzebie Jezdigerda III i o istnieniu chrześcijańskiego monasteru (masarjan) w Merw. Współczesne, nowe dane archeologiczne potwierdzają te informacje.

Islam miał pewną przewagę, ale wraz z Mongołami nadchodziły nowe czasy. Wszystko się miało zmienić. W drugiej połowie IX wieku wielkie państwo muzułmańskie rozpadło się na małe, niezależne państewka rządzone przez lokalne dynastie. Zarówno chrześcijanie, jak i muzułmanie znajdowali się w centrum tych wydarzeń. Najazdy mongolskie niszczyły kwitnące miasta, ale nie był to atak ani na chrześcijan, ani na muzułmanów. Sam Czyngis-chan wydał niektórych ze swoich synów za chrześcijanki. Chrześcijanie mieli dostęp do funkcji państwowych. Kolejny chan - Mangu (1251-1260) - o mało nie został chrześcijaninem, a jego brat Hulagu, zdobywca Bagdadu w 1258 roku i założyciel cha-

${ }_{55}$ Por. E.C.D. Hunter, The Conversion of the Kerait to Christianity in A.D. 1009, „Zentralasiatische Studien" 22 (1989), s. 142-163. 
natu Persji, miał żonę chrześcijankę i podobno wyznawał wiarę chrześcijańską. $\mathrm{W}$ większych miastach najeźdźcy pozwolili nawet odbudować kościoły i praktykować wiarę. Oczywiście, pomimo tolerancji chana wielu chrześcijanom, jak i muzułmanom, stale groziła śmierć i utrata majątku, lecz nie ze względu na wyznanie. W armii mongolskiej też służyli chrześcijanie. Wydaje się, że władcy mongolscy byli bardziej praktykami i kierowali się swoim interesem, a nie kwestiami religijnymi.

Blisko więc było do tego, by Mongołowie stali się chrześcijanami. Islam przyjął wpierw władca zachodniej Persji Ahmad (1280-1284). Został on za to potępiony przez Kubilaja (na wschodzie), a także przez swego następcę Arghuna. Sprzyjali oni chrześcijanom, dążąc do sojuszu z europejskimi władcami przeciwko muzułmańskiemu Egiptowi. Świadczy o tym choćby słynna misja Bar Saumy ${ }^{56}$, posłanego w 1287 roku do Europy w roli oficjalnego przedstawiciela chana. Plany ówczesnych europejskich władców i papieży, by zawrzeć z Mongołami wzajemny układ skierowany przeciwko Arabom, nie były więc nierealne. Na tereny Azji Centralnej posyłano kilka misji dyplomatycznych, prowadzonych przez dominikanów i franciszkanów ${ }^{57}$.

Osiągnięcia chrześcijan Wschodu na tak rozległych obszarach wyglądają imponująco, gdy zestawimy je z relatywnie wolnym tempem nawracania się Europy. Chociaż chrześcijaństwo dotarło na kontynent europejski w czasach św. Pawła, dużo czasu upłynęło, zanim wyszło poza świat śródziemnomorski. Frankowie, którzy podbili rzymską Galię, przyjęli wiarę na początku VI wieku, Anglosasi w VII wieku, ale nadal pozostawała „pogańska” większość. Pod koniec VIII wieku Karol Wielki toczył długą wojnę mającą na celu podbój Sasów, którzy dominowali w środkowych Niemczech, a nawrócenie Słowian i Skandynawów zajęło co najmniej dwa stulecia. Polska przyjęła chrześcijaństwo rzymskie w 966 roku, a Ruś Kijowska bizantyńskie w 987 roku. Norwegia i Szwecja znalazły się w procesie nawracania dopiero około roku 1000, a państwo litewskie przyjęło nową religię dopiero w latach osiemdziesiątych XIII wieku.

Jednak w Azji Centralnej, w 1295 roku, to islam stał się oficjalną religią. Odtąd wszyscy chrześcijanie byli narażeni na prześladowania. Timur (1336-1405), który nie był Mongołem, nie podzielał przychylności mongolskich cha-

${ }^{56} \mathrm{Na}$ dworach katolickiej Europy wywołał on sensację. Królowie i biskupi byli zdumieni, gdy odkrywali, że był chrześcijańskim biskupem, całkowicie ortodoksyjnym, jednak odwoływał się nie do władzy duchowej papieża czy bizantyjskiego patriarchy, ale do katolikosa mieszkającego w Mezopotamii. Odkrywali, że świat chrześcijański rozciąga się znacznie dalej, aż do wybrzeży Pacyfiku. Ich gość był przekonany, że jego Kościół jest stale na etapie dalszej ekspansji. Por. P. Jenkins, The Lost History of Christianity. The Thousand-Year Golden Age of the Church in the Middle East, Africa, and Asia - and How It Died, s. 93-95.

${ }^{57}$ Najbardziej znaną jest misja dominikanina Wilhelma z Rubruk. 
nów wobec chrześcijan. Jego najazd w 1394 roku stał się nieszczęściem dla wszystkich mieszkańców Azji Centralnej. Timur niszczył całe miasta bardziej bezwzględnie niż Mongołowie. W tym czasie zniknęła większość wspólnot chrześcijańskich. Ci chrześcijanie, którzy przeżyli, musieli uciekać w górskie, niedostępne rejony ${ }^{58}$.

Oczywiście nie można wykluczyć osobistych przekonań Timura. Marek M. Dziekan w swojej książce, w notatce o At-Taftazanim (1322-1390 $)^{59}$, podaje, że był to „wielki przyjaciel mongolskiego władcy Tamerlana (Timura)”, związany z dworami chanów Złotej Ordy. Prawdopodobnie na decyzję Timura wpłynął interes polityczno-wojskowy wraz z jego osobistymi przekonaniami. Decyzja ta zmieniła losy nie tylko Azji Centralnej, ale i Bliskiego Wschodu, a pośrednio również Europy.

\section{Podsumowanie}

Chrześcijanie na wspominanych w artykule terenach potrafili istnieć przez kilka wieków nawet jako mniejszość religijna w państwie względnie tolerancyjnym (czyli już zakorzenieni), zachowując misyjny zapał. Zmieniły to dopiero uwarunkowania okrutnej wojny. Zatem mowa o wierze w oderwaniu od uwarunkowań społeczno-politycznych jest błędna.

Z chrześcijańskiej perspektywy wydaje się, że najgorszą konsekwencją decyzji Timura było „zduszenie” młodych Kościołów Azji. Wysiłki misyjne wśród Mongołów, Turków i Chińczyków straciły swoje oparcie. Młode Kościoły, jeszcze nie w pełni dojrzałe, zostały odcięte od swoich korzeni i w efekcie stopniowo wymarły. Wiara chrześcijańska nie zdążyła stać się rodzimą. Pozostała religią „obcych” - Syryjczyków - wyrażaną w ich kulturze. Zdążyła przyjąć się w miastach, ale te uległy zniszczeniu. Zabrakło czasu (inkulturacja jest procesem powolnym), by dotarła do ludów koczowniczych ze stepów i pustyń. Styl życia pasterzy-nomadów oraz mieszkańców strefy górskiej, egzystujących w rozproszonych społecznościach, uniemożliwił szybkie stworzenie nowych zwyczajów. Większość ludności tam mieszkającej nie dawała się łatwo przekonać. Sama wiedza religijna nie wystarczyła. Zabrakło czasu, by wykształciła się pobożność ludowa, która wcieliłaby się w zwyczaje rodzimej ludności.

Natomiast islam zachował - w kształcie, w jakim został na początku przyniesiony przez Arabów do Azji Centralnej - swój doktrynalnie uregulowany, formalny charakter w instytucjach miast; w ,terenie” zmodyfikowały go lokalne

${ }^{58}$ Por. A.S. Atiya, Historia Kościołów Wschodnich, Warszawa 1978, s. 182. Por. tamże, s. 236$-237$.

${ }_{59}$ M.M. Dziekan, Pisarze muzułmańscy VII-XX w. Maty stownik, s. 115. 
tradycje i wierzenia. Wśród najważniejszych, „dodanych” zwyczajów znalazł się swoisty kult „świętych”, stanowiący o specyfice islamu tego regionu. Być może był to owoc wpływu istniejącej na owych terenach chrześcijańskiej pobożności.

Wydaje się, że zarówno w perspektywie teologicznej, jak i w religioznawczej warto byłoby przeprowadzić pogłębione porównanie obu sytuacji: po pierwsze, militarnego unicestwienia chrześcijaństwa w Azji Centralnej z analogiczną sytuacją, jaka miała miejsce dwa wieki później na Półwyspie Iberyjskim, gdzie mimo iż wielka, tysiącletnia tradycja muzułmańska została militarnie przerwana w wymiarze zewnętrznym, to przetrwała w kulturze innej religii, oraz po drugie, przetrwania chrześcijaństwa na Kaukazie, które znajdowało się w analogicznej sytuacji, jak w Azji Centralnej, ale stało się religią państwową (Armenia, Gruzja) i przetrwało do dzisiaj.

\section{Christian-Muslim Relations in Central Asia to Timur Time (XIV Century)}

\section{Summary}

Sometimes it is said about the fall of the Christian Culture of the West. It is worth taking a look, therefore, at a certain analogy from seven centuries ago. The first thousand years of development of faith in Asia led to many outstanding theological syntheses. There were also many saint martyrs and missionaries. Christianity also had its experience of faith in the Islamic State. Despite the difficulties, the missionary spirit until the fourteenth century has been developing. The breakthrough occurred only during Timur's times due to Mongolian wars. Why did Timur accept Islam, despite the considerable presence of Christians in his surroundings? There was no lack of outstanding Christian scholars. In addition to possible personal reasons, he probably decided realizing that Sufi Islam is already deeply rooted among the masses of a simple population of Central Asia. An important role in this process played the political current of "Order" Naqshbandiyah.

\section{Keywords}

Central Asia, Oriental Christianity, Nestorians, Merv, Samarkand, Asian Islam, Naqshbandiyah

\section{Słowa kluczowe}

Azja Centralna, chrześcijaństwo orientalne, nestorianie, Merw, Samarkanda, islam azjatycki, nakszbandijja 


\section{Bibliografia}

Akiner S., Islam in Central Asia, w: Encyclopedia of Religion, t. VII, Detroit 2005, s. 4620-4630.

Al-Buchari S., Zbiór wiarygodnych hadisów Proroka Muhammada, tłum. P. Ziółkowski, Poznań 2018.

Atiya A.S., Historia Kościołów Wschodnich, Warszawa 1978.

Brill Olcott M., Sufism in Central Asia. A Force for Moderation or a Cause of Politicization?, „Carnegie Papers” 84 (2007) (Carnegie Endowment for International Peace Russian and Earasian Program).

Can M., Emergence of Islamic Sciences in Merv (First Two Centuries A.H.), „Mütefekkir" 3 (2016) nr 6, s. 399-425.

Cieciura W., Muzutmanie chińscy. Historia, religia, tożsamość, Warszawa 2014.

Comneno M.A.L., Nestorianism in Central Asia during the First Millennium: Archaeological Evidence, „Journal of the Assyrian Academic Society” 11 (1997), s. 20-53.

Daniélou J., Teologia judeochrześcijańska. Historia doktryn chrześcijańskich przed Soborem Nicejskim, tłum. S. Basista, Kraków 2002.

Deeg M., Chinese Buddhists in Search of Authenticity in the Dharma, „The Eastern Buddhist" 45 (2014) nr 1-2, s. 11-22.

Dillon M., Islam in China, w: Encyclopedia of Religion, t. VII, Detroit 2005, s. 46304640 .

Dziekan M.M., Pisarze muzułmańscy VII-XX w. Mały słownik, Warszawa 2003.

Francavilla C., The site of Shaym Qal'a, Marw oasis: reconsidering the chain of information, „Historia i Świat” 8 (2019), s. 79-90.

Gafurow B., Dzieje i kultura ludów Azji Centralnej. Prehistoria. Starożytność. Średniowiecze, thum. S. Michalski, Warszawa 1978.

Gumiłow L., Śladami cywilizacji Wielkiego Stepu, tłum. S. Michalski, Warszawa 2004.

Hartmann J.-U., Buddhism in Central Asia, w: Encyclopedia of Religion, t. II, Detroit 2005, s. 1144-1148.

Hoogerwerf C., Historische versus allegorische uitleg in de inleiding van Išo 'dad van Mervs commentaar op de Psalmen: Vertaling en bronkritische analyse, „NTT Journal for Theology and the Study of Religion" 73 (2019) nr 4, s. 283-297.

Hopkirk P., Obce diabty na Jedwabnym Szlaku. W poszukiwaniu zaginionych miast i skarbów w chińskiej części Azji Środkowej, tłum. A. Bezpiańska-Oglęcka, Warszawa 2008.

Hunter E. C.D., Syriac Christianity in Central Asia, „Zeitschrift für Religions- und Geistesgeschichte" 44 (1992) s. 362-368.

Hunter E. C.D., The Conversion of the Kerait to Christianity in A.D. 1009, „Zentralasiatische Studien" 22 (1989), s. 142-163.

Jan Paweł II, Dinka IV, Wspólna deklaracja chrystologiczna Kościoła katolickiego i Asyryjskiego Kościoła Wschodu, „Studia Theologica Varsaviensia” (1997) nr 2, s. 349- 
-351. Tekst oryginalny https:/www.vatican.va/content/john-paul-ii/en/speeches/ 1994/november/documents/hf_jp-ii_spe_19941111_dichiarazione-cristologica.html [dostęp 04.08.2021].

Jenkins Ph., The Lost History of Christianity. The Thousand-Year Golden Age of the Church in the Middle East, Africa, and Asia - and How It Died, New York 2008.

Jessa P., „Przyjaciele Allaha”. Kult muzutmańskich świętych w Azji Środkowej, Poznań 2009.

Klimkeit H.-J., Buddhism in Turkish Central Asia, „Numen” 37 (1990), s. 53-69.

Kluj W., Chrześcijaństwo w starożytności i średniowieczu na terytoriach współczesnego Turkmenistanu, w: Turkmenistan. Historia - społeczeństwo - polityka, red. T. Bodio, Warszawa 2005, s. 479-485.

Kluj W., Zmienne dzieje Kościoła w Azji Środkowej, w: „Ecclesia in Asia”. Wybrane problemy Kościoła w Azji w świetle posynodalnej adhortacji Jana Pawła II, red. J. Różański, Warszawa 2004, s. 143-159.

Landowski Z., Sufizm. Podstawowe informacje, Warszawa 2010.

Latourette K.S., A History of the Expansion of Christianity, t. II: The Thousand years of Uncertainty, A.D.500-A.D.1500, Grand Rapids 1973.

Maciak M., Muzułmańskie pielgrzymowanie w krajach Azji Centralnej (rozprawa doktorska), Warszawa 2018.

McDonough S., A Second Constantine? The Sasanian King Yazdgard in Christian History and Historiography, „Journal of Late Antiquity” 1 (2008) nr 1, s. 127-140.

Muslim Saints and Mystics. Episodes from the Memorial of the Saints by Farid al-Din Attar, Ames 2000.

Nattier J., Church Language and Vernacular Language in Central Asian Buddhism, „Numen” 37 (1990), s. 195-219.

Nautin P., L'auteur de la "Chronique anonyme de Guidi»: Élie de Merw, „Revue de l'histoire des religions" 199 (1982) nr 3, s. 303-314.

Panchenko C.A., Orthodoxy and Islam in the Middle East. The Seventh to the Sixteenth Century, Jordanville 2021.

Philip T.V., The Missionary Impulse in the Early Asian Christian Traditions, „Journal of International Review of Mission" 85 (1996), s. 508-509.

Sadowski M., ,, Trzecie pluco” chrześcijaństwa? Jan Pawet II a Kościoły tradycji syryjskiej, „Studia Włocławskie” 16 (2014), s. 245-261.

Sander L., Buddhist Literature in Central Asia, w: Encyclopaedia of Buddhism, red. G.P. Malalasekera, t. IV, Colombo 1979, s. 52-75.

The Commentaries of Isho 'dad of Merv, Bishop of Hadatta (c. 850 A.D.) in Syriac and English, red. M.D. Gibson, t. I-V, Cambridge 1911-1916.

Uciecha A., Adam i Ewa we wschodnio-syryjskiej egzegezie Iszodada z Merw (Rdz 2,21-24): stan badań, komentarz i przekład, „Śląskie Studia Historyczno-Teologiczne" (2016) z. 2, s. 302-310. 
Uciecha A., Egzegeza biblijna w komentarzach syryjskich Afrahata, Efrema, Iszodada z Merw i Teodora Bar Koni: zarys problematyki, „Vox Patrum” 67 (2017), s. 673686.

Utz D.A., A Survey of Buddhist Sogdian Studies, Tokyo 1978.

Wood Ph., The Chronicle of Seert: Christian Historical Imagination in Late Antique Iraq, Oxford 2013.

Yakubovskii A.Yu, Bosworth C.E., Marw al-Shahidjan, w: Encyclopédie de l'Islam, t. VI, Leiden-Paris 1991, s. 603-606.

Żerańska-Kominek S., Lebeuf A., Opowieść o szalonej Harman i Aszyku zakochanym w księżycu. Postać muzyka i koncepcja muzyki w turkmeńskim dessanie „Harman Däli”, Kraków 1998. 